Volume 4 No 1 September 2018 p-ISSN : 2460-8750 e-ISSN : 2615-1731

\title{
HUBUNGAN ANTARA KECERDASAN EMOSIONAL DENGAN KOMPETENSI KEPRIBADIAN GURU
}

\author{
Ahmad Razak ${ }^{1 *}$, Novita Maulidya Jalal ${ }^{2}$ \\ ${ }^{12}$ Fakultas Psikologi, Universitas Negeri Makassar. Indonesia \\ Email: Ahmadrazak71@yahoo.co.id ${ }^{1}$, novitamaulidya@ yahoo.com ${ }^{2}$ \\ (C) 2018 -JPT Fakultas Psikologi Universitas Negeri Makassar. Ini adalah artikel dengan \\ akses terbuka dibawah licenci CC BY-NC-4.0 (https://creativecommons.org/licenses/by-nc/4.0/ ).
}

\begin{abstract}
Abstrack. This study examines the relationship between emotional intelligence and personality competence. The subjects of this study were 60 teachers of SMAN 1 Sungguminasa using total sampling techniques. Data retrieval used by using The emotional intelligence scale and personality competency scale. The data was then processed using parametric statistics, namely Pearson product moment. The results of the analysis show that there is a relationship between emotional intelligence and personality competence. This shows that there is a positive relationship between emotional intelligence and personality competence. The higher the emotional intelligence, the higher the personality competence.
\end{abstract}

Keywords: Emotional Intelligence, Personality Competence

Abstrak. Studi ini meneliti tentang hubungan antara kecerdasan emosional dengan kompetensi kepribadian. Subjek penelitian ini adalah guru SMAN 1 Sungguminasa sebanyak 60 dengan menggunakan teknik total sampling. Pengambilan data dilakukan dengan menggunakan skala kecerdasan emosional dan skala kompetensi kepribadian. Data kemudian diolah dengan menggunakan statistik parametrik yaitu pearson product moment. Hasil analisis menunjukkan bahwa ada hubungan antara kecerdasan emosional dengan kompetensi kepribadian. Ini menunjukkan bahwa ada hubungan positif antara kecerdasan emosional dengan kompetensi kepribadian. Semakin tinggi kecerdasan emosional, maka semakin tinggi kompetensi kepribadian.

Kata Kunci: Kecerdasan Emosional, Kompetensi Kepribadian

\section{PENDAHULUAN}

Berdasarkan Undang-Undang

Nomor 20 Tahun 2003 pasal 1 ayat 1 tentang Sistem Pendidikan Nasional dinyatakan bahwa pendidikan adalah usaha sadar dan terencana untuk mewujudkan suasana belajar dan proses pembelajaran agar peserta didik secara aktif mengembangkan potensi dirinya untuk memiliki kekuatan spiritual keagamaan, pengendalian diri, kepribadian, kecerdasan, akhlak mulia, serta keterampilan yang diperlukan dirinya, masyarakat bangsa dan negara. (Depdiknas, 2003).

Terkait dengan hal tersebut di atas maka guru adalah salah satu komponen utama dalam pendidikan yang sangat berperan di dalamnya, oleh karena gurulah yang berinteraksi secara langsung dengan 
70 I Jurnal Psikologi Talenta Vol 4 No. 1

anak didik setiap saat. Bahkan lebih jauh dijelaskan bahwa guru adalah pendidik profesional dengan tugas utama mendidik, mengajar, membimbing, mengarahkan, melatih, menilai, dan mengevaluasi peserta didik pada pendidikan anak usia dini jalur pendidikan formal, pendidikan dasar, dan pendidikan menengah (Undang-undang Republik Indonesia Nomor 14 2005).

Bloom menyatakan bahwa ada tiga domain yang mesti dibentuk oleh seorang guru terhadap siswa yaitu: kognitif, affective, dan psychomotor (Bloom, 1956). Seiring dengan itu pula UNESCO lebih mempertegas lagi bahwa konsep pendidikan yang harus diterapkan guru di sekolah meliputi empat pilar, yakni: belajar berfikir (learning to think), belajar berbuat (learning to do), belajar mengaktualisasikan diri (learning to be), dan belajar untuk hidup bersama (learning to gether) (Tilaar, 1997).

Sedemikian berat tugas dan tanggung jawab guru sehingga ia dituntut untuk memiliki kompetensi, yaitu: kompetensi paedagogik, kompetensi kepribadian, kompetensi sosial, dan kompetensi professional (Arief, 2006). Guru dalam kapasitasnya sebagai teladan atau panutan dari anak didiknya maka sangat dituntu untuk memiliki kompetensi kepribadian yang mantap yang dapat dijadikan sebagai idola. Oleh karena itu
Hubungan Kecerdasan Emosional dengan Kompetensi

seluruh aspek kehidupan guru idealnya menjadi figure yang paripurna.

Di era sekarang ini, tidak sedikit kasus yang mencoreng citra dan prefesi guru oleh karena ulah guru yang tidak mencerminkan kepribadiannya sebagai seorang guru. Tidak jarang kasus guru diberitakan di media massa seperti kasus sabu-sabu, kasus pencabulan, kasus kekerasan terhadap anak didiknya dan sebagainya. Fenomena tersebut adalah sangat ironis dengan cita kepribadian guru yang sesungguhnya.

Oleh karena itu sangat penting bagi seorang guru memiliki sikap dan kepribadian yang dapat diteladani. Memang diakui bahwa kepribadian sangatlah abstrak dan sukar untuk diketahui secara riil, tetapi dapat diketahui lewat penampilan, tindakan, dan atau ucapan ketika menghadapi suatu persoalan.

Gordon Allport (Robbins, 2003) mengungkapkan bahwa kepribadian itu pada dasarnya merupakan satu kesatuan sistem fisik dan psikologis dalam diri individu yang menentukan penyesuaian uniknya terhadap lingkungan. Hal ini sejalan dengan definisi kepribadian dari Kartono (2005) yakni bagian dari diri seseorang yang secara langsung berhubungan dengan kapasitas psikis seseorang, yang berkaitan dengan nilai-nilai etis atau kesusilaan dan tujuan hidup. Selain itu, kepribadian menurut Kartono 
(Nursyamsi, 2014) juga diartikan sebagai totalitas dari efek-efek yang ditimbulkan oleh individu terhadap masyarakat.

Kepribadian mencakup semua unsur, baik fisik maupun psikis. Sehingga dapat diketahui bahwa setiap tindakan dan tingkah laku seseorang merupakan cerminan dari kepribadian seseorang, selama hal tersebut dilakukan dengan penuh kesadaran. Setiap perkataan, tindakan, dan tingkah laku positif akan meningkatkan citra diri dan kepribadian seseorang. Begitu naik kepribadian seseorang maka akan naik pula wibawa orang tersebut. Kepribadian akan turut menetukan apakah para guru dapat disebut sebagai pendidik yang baik atau sebaliknya, justru menjadi perusak anak didiknya. Sikap dan citra negatif seorang guru dan berbagai penyebabnya seharusnya dihindari jauh-jauh agar tidak mencemarkan nama baik guru. Kini, nama baik guru sedang berada pada posisi yang tidak menguntungkan, terperosok jatuh. Para guru harus mencari jalan keluar atau solusi bagaimana cara meningkatkan kembali sehingga guru menjadi semakin berwibawa, dan terasa sangat dibutuhkan anak didik dan masyarakat luas.

Guru sebagai teladan bagi muridmuridnya harus memiliki sikap dan kepribadian utuh yang dapat dijadikan tokoh panutan idola dalam seluruh segi kehidupannya. Karenanya guru harus selalu berusaha memilih dan melakukan perbuatan yang positif agar dapat mengangkat citra baik dan kewibawaannya, terutama di depan murid-muridnya. Disamping itu guru juga harus mengimplementasikan nilai-nilai tinggi terutama yang diambilkan dari ajaran agama, misalnya jujur dalam perbuatan dan perkataan, tidak munafik. Sekali saja guru didapati berbohong, apalagi langsung kepada muridnya, niscaya hal tersebut akan menghancurkan nama baik dan kewibawaan sang guru, yang pada gilirannya akan berakibat fatal dalam melanjutkan tugas proses belajar mengajar.

Sikap positif dari kepribadian merupakan tanda adanya kematangan dari kepribadian seseorang sebagaimana dikemukakan oleh beberapa tokoh (Kartono,2005) yakni individu yang dapat menguasai lingkungannya secara aktif, individu dapat memperlihatkan suatu totalitas dari segenap kepribadiannya, individu sanggup menerima secara tepat dunia lingkungannya dan dirinya sendiri, serta individu mampu berdiri mandiri tanpa banyak menuntut kepada orang lain.Hal tersebut juga sejalan dengan pendapat Erikson (Nursyamsi,2014) bahwa pribadi yang matang merupakan pribadi yang memiliki organisasi usaha yang efektif untuk mencapai tujuan hidupnya, ia dapat menerima realitas dunia secara nyata, mampu melakukan hubungan interpersonal yang baik, serta memiliki integritas karakter yang baik. 
Berdasarkan hasil penelitian dari Riadi (tanpa tahun) menyatakan bahwa salah satu faktor yang berhubungan langsung dengan kepribadian guru adalah kecerdasan emosi. Menurut Daniel Goleman (Kinicky dan Kreitner,2008) memberikan batasan bahwa kecerdasan emosional merupakan kemampuan untuk mengelola diri sendiri dan hubungan seseorang dengan cara dewasa dan konstruktif yang sebagian orang menyebutnya sebagai Emotional Intelligency (EI). Kecerdasan emosional adalah salah satu faktor yang mendukung terbangunnya kompetensi kepribadian bagi setiap orang. Kecerdasan emosional merupakan kemampuan untuk memotivasi diri sendiri, bertahan menghadapi frustasi, mengadakan dorongan hati, tidak melebihlebihkan kesenangan,mengatur suasana hati, dan menjaga agar beban stress (tekanan mental) tidak melumpuhkan kemampuan berpikir, punya empati dan banyak berdoa.(Goleman,1995).

Kecerdasan emosional tumbuh seiring pertumbuhan seseorang sejak lahir hingga meninggal dunia. Pertumbuhan kecerdasan emosional dipengaruhi oleh lingkungan, keluarga, dan contoh-contoh yang didapat seseorang sejak lahir dari orang tuanya. Kecerdasan emosional menyangkut banyak aspek penting, yang agaknya semakin sulit didapatkan pada manusia modern, yaitu: empati (memahami orang lain secara mendalam), mengungkapkan dan memahami perasaan, mengendalikan amarah, kemandirian, kemampuan menyesuaikan diri, disukai, kemampuan memecahkan masalah antar pribadi ketekunan, kesetiakawanan, keramahan, dansSikap hormat (Sri Hastuti, 2012).

Beberapa karakteristik kecerdasan emosi menjadi 5 dimensi menurut Daniel Goleman (Luthan, 2008) antara lain (1) self awareness yakni pemahaman diri, pengetahuan tentang perasaan yang sebenarnya saat ini, (2) self management adalah kemampuan menangani adalah kemampuan menangani emosi untuk memfasilitasi bukan menghalangi, dan melepaskan emosi negatif kemudian kembali ke jalur yang konstruktif untuk pemecahan masalah, (3) self motivation adalah keteguhan dalam menuju tujuan yang diinginkan, mengatasi dorongan emosi negatif dan menunda kepuasan untuk mencapai hasil yang diinginkan kemudian keteguhan dalam menuju tujuan yang diinginkan, mengatasi dorongan emosi, (4) emphaty adalah memahami dan peka terhadap perasaan orang lain, mampu merasakan apa yang orang lain rasakan dan inginkan, (5) social skill adalah kemampuan untuk membaca situasi sosial, luwes dalam berinteraksi dengan orang lain, serta mampu mengarahkan emosi orang lain dan cara, tindakannya. 
Oleh karena bagi seorang guru sangat penting untuk membangun emosi yang positif di dalam dirinya. Sebab bagaimanapun juga hal tersebut dapat menjadikan terbentuknya kompetensi kepribadian dalam diri individu. Menurut Cooper (1999) bahwa kecerdasan emosi memungkinkan individu untuk dapat merasakan dan memahami dengan benar, selanjutnya mampu menggunakan daya dan kepekaan emosinya sebagai energi informasi dan pengaruh yang manusiawi. Sebaliknya bila individu tida memiliki kematangan emosi maka akan sulit mengelola emosinya secara baik dalam bekerja. Disamping itu individu akan menjadi pekerja yang tidak mampu beradaptasi terhadap perubahan, tidak mampu bersikap terbuka dalam menerima perbedaan pendapat, kurang gigih dan sulit berkembang. Selanjutnya Howes dan Herald (Widodo, 2002) mengatakan bahwa pada intinya, kecerdasaan emosional merupakan komponen yang membuat seseorang menjadi pintar menggunakan emosi. Lebih lanjut dijelaskan bahwa emosi manusia berada diwilayah dari perasaan lubuk hati, naluri yang tersembunyi, dan sensasi emosi yang apabila diakui dan dihormati, kecerdasaan emosional menyediakan pemahaman yang lebih mendalam dan lebih utuh tentang diri sendiri dan orang lain. Menurut Harmoko (2005) Kecerdasan emosi dapat diartikan kemampuan untuk mengenali, mengelola, dan mengekspresikan dengan tepat, termasuk untuk memotivasi diri sendiri, mengenali emosi orang lain, serta membina hubungan dengan orang lain. Jelas bila seorang indiovidu mempunyai kecerdasan emosi tinggi, dapat hidup lebih bahagia dan sukses karena percaya diri serta mampu menguasai emosi atau mempunyai kesehatan mental yang baik.

Dari beberapa pendapat diatas dapatlah dikatakan bahwa kecerdasan emosional menuntut diri untuk belajar mengakui dan menghargai perasaan diri sendiri dan orang lain dan untuk menanggapinya dengan tepat, menerapkan dengan efektif energi emosi dalam kehidupan dan pekerjaan sehari-hari. 3 (tiga) unsur penting kecerdasan emosional terdiri dari : kecakapan pribadi (mengelola diri sendiri); kecakapan sosial (menangani suatu hubungan) dan keterampilan sosial (kepandaian menggugah tanggapan yang dikehendaki pada orang lain). Berdasarkan urian di atas menarik untuk diteliti hubungan antar Kecerdasan Emosional dengan Kompetensi Kepribadian pada Guru.

\section{METODE}

Jenis penelitian ini adalah penelitian korelasi product moment. Penelitian ini ingin melihat hubungan antara kecerdasan emosional dengan kompetensi kepribadian 
guru. Subjek penelitian ini adalah guruguru SMAN 1 Sungguminasa Kab. Gowa. Subjek diperoleh dengan teknik total sampling. Keseluruhannya berjumlah 60 orang.

Instrumen yang digunakan untuk memperoleh data penelitian meliputi:

1. Pengukuran kecerdasan emosional. Pengukuran kecerdasan emosional disusun oleh peneliti dengan mengacu kepada indikator Kecerdasan Emosional Goleman (1995). Skala ini tersusun atas 6 aspek/dimensi, yaitu: a) kesadaran diri b) kendali dorongan hati c) kemampuan memotivasi diri sendiri d) kemampuan optimis e) kemampuan sosial dan e) kemampuan berempati. Jumlah item skala kecerdasan emosional dari 36 item yang diujicobakan, 31 item dinyatakan valid karena memiliki korelasi item total di atas 0,30, dan 5 item gugur karena korelasi item totalnya di bawah 0,30, sehingga untuk penelitian hanya menggunakan 31 item setelah sebelumnya dilakukan kembali penomoran ulang setelah mengeluarkan aitem yang tidak valid. Koefisien korelasi kesahihan butir skala ini bergerak dari 0,333 sampai 0,778 . Reliabilitas skala kecerdasan emosi melalui teknik Alpha Cronbach diperoleh Alhpa sebesar 0,926. Ini berarti bahwa skala kecerdasan emosi memiliki tingkat keandalan yang tinggi dan dapat digunakan dalam penelitian.

2. Pengukuran kompetensi kepribadian. Pengukuran kompetnsi kepribadian disusun oleh peneliti dengan mengacu kepada indikator kompetensi kepribadian yang tercantum dalam Undang-Undang Republik Indonesia nomor 14 tahun 2005 tentang undang-undang guru dan dosen, yaitu: (1) berakhlak mulia, (2) arif dan bijaksana, (3) mantap, (4) berwibawa, (5) stabil, (6) dewasa, (7) jujur, (8) mampu menjadi teladan bagi peserta didik dan masyarakat, (9) secara objektif mengevaluasi kinerja sendiri, dan (10) mengembangkan diri secara mandiri dan berkelanjutan. Jumlah item skala kompetensi kepribadian Dari 60 aitem yang diujicobakan, 46 item dinyatakan valid karena memiliki korelasi item total di atas 0,30, dan 14 item gugur karena korelasi item totalnya di bawah 0,30 , sehingga untuk penelitian hanya menggunakan 56 item setelah sebelumnya dilakukan kembali penomoran ulang setelah mengeluarkan aitem yang tidak valid. Koefisien korelasi kesahihan butir skala ini bergerak dari 0,304 sampai 0,866. Reliabilitas skala kecerdasan emosi melalui teknik Alpha Cronbach diperoleh Alhpa sebesar 0,937. Ini berarti bahwa skala kecerdasan emosi 
memiliki tingkat keandalan yang tinggi dan dapat digunakan dalam penelitian.

\section{HASIL DAN PEMBAHASAN}

A. Deskripsi Hasil Penelitian

Guru-guru yang dilibatkan adalah guru-guru SMA Negeri 1 Sungguminasa sebanyak 60 orang, yang selanjutnya diikutkan dalam unit dianalisis. Data tentang kecerdasan emosional, dan kompetensi kepribadian dideskripsikan secara statistik dalam tabel 1.

Tabel 1. Deskripsi statistik data penelitian

\begin{tabular}{|l|c|c|c|c|c|c|c|c|}
\hline \multirow{2}{*}{ Variabel } & \multicolumn{2}{|c|}{$\begin{array}{c}\text { Skor } \\
\text { hipotetik }\end{array}$} & \multirow{2}{*}{ Rerata } & \multirow{2}{*}{ SD } & \multicolumn{2}{c|}{$\begin{array}{c}\text { Skor } \\
\text { empirik }\end{array}$} & \multirow{2}{*}{ rerata } & \multirow{2}{*}{ SD } \\
\cline { 2 - 3 } & $\min$ & $\max$ & & & $\min$ & $\max$ & \\
\hline $\begin{array}{l}\text { Kecerdasan } \\
\text { Emosional }\end{array}$ & 31 & 124 & 77.5 & 15.5 & 92.00 & 109.00 & 102.2833 & 3.74207 \\
\hline $\begin{array}{l}\text { Kompetensi } \\
\text { Kepribadian }\end{array}$ & 46 & 184 & 115 & 23 & $\begin{array}{c}136.0 \\
0\end{array}$ & 180.00 & 163.8000 & 3.78710 \\
\hline
\end{tabular}

Skala Kecerdasan Emosional, jumlah itemnya sebanyak 31. Skor terendah: 31, dan skor tertinggi: 124. Sehingga Skor rerata hipotetik (mean hypotetic) $31+124: 2=77.5$. Adapun Standard Deviasi hipotetik adalah 124-31:6=15.5 Dengan demikian dapat disimpulkan bahwa skor rerata empiris lebih besar daripada skor rerata teoritik, dan bermakna bahwa Kecerdasan emosional guru SMAN 1 Sungguminasa tergolong tinggi.

Skala Kompetensi Kepribadian, jumlah itemnya sebanyak 46. Skor terendah: 46, dan skor tertinggi: 184. Sehingga skor rerata hipotetik (mean hypotetic) $46+184: 2=115$. Adapun Standard Deviasi hipotetik adalah 184-46:6=23 Dengan demikian dapat disimpulkan bahwa skor rerata empiris lebih besar daripada skor rerata teoritik, dan bermakna bahwa kompetensi kepribadian guru SMAN 1 Sungguminasa tergolong tinggi.

B. Hasil Uji Prasyarat Analisis

Penelitian ini tergolong dalam penelitian korelasional dan menggunakan teknik analisis Korelasi Product Moment Pearson. Analisis ini mendasarkan diri atas sejumlah asumsi (Hadi, dkk., 1996), yaitu: (1) cuplikan dibentuk menurut prinsipprinsip pencuplikan rambang, variabel penelitian mengikuti sebaran normal, dan (3) korelasi antara $\mathrm{X}$ dengan $\mathrm{Y}$ adalah linier. Seluruh proses pengujian dilakukan dengan bantuan program SPSS 17.

\section{Uji normalitas sebaran}

Analisis normalitas sebaran variabel dalam penelitian ini menggunakan model 
statistik one sample kolmogorov smirnov test. Kaidah yang digunakan untuk mengetahui normalitas sebaran adalah jika $\mathrm{p}>0,05$, dan jika $\mathrm{p}<0,05$ sebarannya dinyatakan tidak normal.

Pengujian normalitas sebaran variabel kecerdasan emosional menunjukkan nilai $\mathrm{p}=0,394$, variabel kompetensi kepribadian menunjukkan nilai $p=0,147$ atau $p>0,05$. Ini berarti sebaran variabel bebas dan terikat adalah normal sehingga variabel tersebut dianggap memenuhi asumsi untuk keperluan analisis data penelitian.

\section{Uji linieritas hubungan}

Pengujian ini dimaksudkan untuk membuktikan apakah variabel bebas mempunyai hubungan yang linier dengan variabel terikat. Model statistik yang digunakan adalah regresi dan mengacu pada asumsi bahwa hubungan akan linier jika harga $p>0,05$ untuk hubungan variabel bebas dengan variabel terikat. Hasil pengujian menunjukkan bahwa variabel $\mathrm{X}$ dengan $\mathrm{Y}$, menghasilkan nilai $\mathrm{F}$ sebesar 1,804 dengan nilai $\mathrm{p}=0,068$ atau $\mathrm{p}>0,05$, sehingga dinyatakan bahwa variabel bebas $\mathrm{X}$ memiliki korelasi yang linier dengan variabel terikat Y. Karena itu, variabel penelitian dapat memenuhi asumsi bagi keperluan analisis berikutnya.

\section{Hasil Pengujian Hipotesis}

Hipotesis penelitian yang diuji adalah adanya hubungan positif antara kecerdasan emosional dengan kompetensi kepribadian guru. Semakin tinggi tingkat kecerdasan emosional guru semakin baik atau tinggi kompetensi kepribadiannya. Berdasarkan hasil analisis diperoleh harga koefisien korelasi sebesar 0,495 dengan peluang ralat $\mathrm{p}=0,000$, maka merujuk pada kaidah uji hasil penelitian (KUHP) alternatif (Hadi, 2000) diperoleh hasil pengujian signifikan. Ini berarti bahwa prediktor kecerdasan emosional menunjukkan korelasi yang signifikan dengan penyesuaian kompetensi kepribadian guru. Koefisien korelasi (rxy) sebesar 0,495. Untuk lebih jelasnya dapat diketahui pada table 2 .

Tabel 2. Korelasi antara kecerdasan emosional dengan kompetensi kepribadian

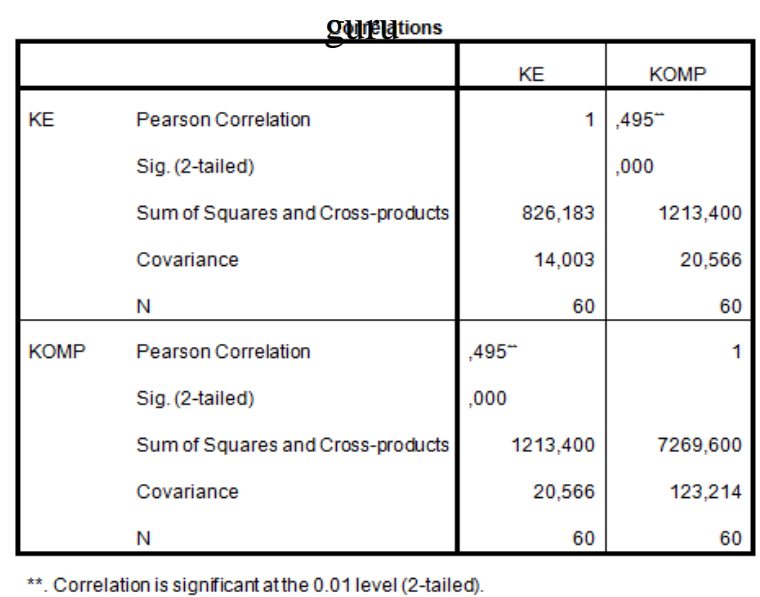

Berdasarkan hal tersebut dapat disimpulkan bahwa terdapat korelasi yang positif antara kecerdasan emosional dengan kompetensi kepribadian guru. Dengan demikian, hipotesis yang diajukan dapat diterima, yaitu semakin tinggi kecerdasan 
emosional maka akan semakin tinggi atau semakin baik kompetensi kepribadian guru.

\section{Pembahasan}

Adanya korelasi positif antara variabel kecerdasan emosional dengan kompetensi kepribadian menunjukkan bahwa semakin tinggi tingkat kecerdasan emosional seseorang maka akan semakin baik kompetensi kepribadian

Hasil penelitian ini sekaligus memperkuat hasil penelitian sebelumnya bahwa kecerdasan emosional yang tinggi secara signifikan juga memiliki skor selfmonitoring, skor empati, skor social skill, dan skor hubungan interpersonal yang tinggi (Schutte, dkk 2001). Denham, dkk, (2001) juga menjelaskan bahwa kecerdasan emosional akan membentuk kompetensi emosi dalam diri anak yang akan membentuk kompetensi sosial. Anak yang kurang memiliki kompetensi sosial akan memperlihatkan respon emosi yang negatif seperti kurang bahagia dan kurang ceria dalam bermain.

Bethania (2013) juga menjelaskan bahwa kecerdasan emosional memberikan pengaruh signifikan terhadap peran ganda pada guru wanita. Ia menguraikan bahwa tugas utama seorang wanita adalah mengasuh dan melayani suami, namun tidak bisa dipungkiri bahwa perkembangan gender sekarang semakin maju sehingga banyak wanita yang berperan ganda.
Disamping ia sebagai ibu rumah tangga juga mampu memberdayakan dirinya dengan berbagai aktifitas yangproduktif. Hasil penelitian ini membuktikan bahwa kecerdasan emosional terbukti signifikan berpengaruh terhadap peran gender wanita. Sejalan dengan itu Ratnasari dan Muttaqhiyatun (2010) juga mengungkapkan bahwa kecerdasan emosional berkorelasi positif terhadap kinerja guru. Nurlaili (2010) juga menjelaskan bahwa kecerdasan emosional berpengaruh terhadap kemandirian dan kepatuhan bagi diri seorang remaja.

Berdasarkan hasil uji yang menunjukkan adanya korelasi signifikan kecerdasan emosional dengan kompetensi kepribadian, memberikan makna bahwa bentuk kecerdasan emosional penting untuk dimiliki dan dikembangkan bagi seorang guru agar semakin memperbaiki kompetensi kepribadiannya. Guru yang memiliki kompetensi kepribadian yang baik akan memberikan dampak positif terhadap lingkungan kerjanya dan terutama sekali kepada anak didiknya. Sebab bagaimanapun juga harus diakui bahwa kepribadian adalah elemen dasar seorang guru dalam membina hubungan yang harmonis dengan anak didiknya. Karena didalamnya berisi elemen nilai nilai kehidupan ,empati dan membina relasi dengan orang lain. Seorang guru yang memiliki kompetensi kepribadian dapat 
78 I Jurnal Psikologi Talenta Vol 4 No. 1

menghayati peran statusnya sebagai guru, mengenali dan mengendalikan emosi sendiri serta mengahragai siswa.

\section{KESIMPULAN}

\section{Simpulan}

Kesimpulan yang dapat ditarik

berdasarkan hasil penelitian ini adalah:

1. Kecerdasan emosional guru SMAN 1 Sungguminasa tergolong tinggi.

2. Kompetensi kepribadian guru SMAN 1 Sungguminasa tergolong tinggi.

3. Ada korelasi positif antara kecerdasan emosional dengan kompetensi kepribadian, makin tinggi kecerdasan emosional guru, makin tinggi pula kompetensi kepribadian guru.

\section{Saran}

1. Bagi para guru, berdasarkan hasil penelitian bahwa betapa pentingnya kecerdasan emosional sebagai modal utama dalam membangun kompetensi kepribadian untuk memnghadapi tantangan global. Sehingga disarankan agar para guru terus mengaktualkan kecerdasan emosionalnya

2. Peneliti selanjutnya yang berminat untuk meneliti lebih lanjut mengenai hubungan antara kecerdasan emosional dengan kompetensi kepribadian pada guru, perlu menambahkan variabel lain yang diduga turut mempengaruhi
Hubungan Kecerdasan Emosional dengan Kompetensi

kemampuan penyesuaian diri pada mahasiswa seperti spiritual, dukungan sosial, dan konsep diri. Selain itu, juga dapat dilakukan penambahan jumlah sampel dan unit atau lokasi penelitian yang lebih banyak dan luas sehingga hasil penelitiannya dapat dijadikan dasar untuk generalisasi.

\section{DAFTAR PUSTAKA}

Arief, I. 2006. Implementasi UndangUndang Guru dan Dosen. Makalah. Disajikan pada Seminar Nasional di UNM pada Tanggal 29 Juli 2006.

Bethania, Martha. 2013. Hubungan antara kecerdasan emosional dengan konflik peran ganda pada guru wanita di surabaya. Jurnal Psikologi Pendidikan dan Perkembangan, 2 (1): 1-7.

Bloom B.S. 1956. Taxonomy of Educational Objectives The Classification of Educational Goals. london: Longman Goup Ltd.

Cooper, R.K, and Ayman, S. 1999. Executive Emotional Quetiont, Kecerdasan Emosional dalam Kepemimpinan dan Organisasi, Alih Bahasa : Alex Tri, K.W. Jakarta : Gramedia Pustaka Utama.

Denham, S., Mason, T., Caverly, S., Schmidt, M,. Hackney, R., Caswel, C., and DeMulder. E. 2001. Preschoolers at Play : Co-socialisers of Emotional and Social Competence. International Journal of Behavioral Development, 25,4,290-301.

Depdiknas. Undang-Undang Republik Indonesia. Nomor 20 Tahun 2003 tentang Sistem Pendidikan Nasional.

Depdiknas. 2005. Undang-Undang Republik Indonesia Nomor 14 Tahun 2005 Tentang Guru dan Dosen, Jakarta: Depdiknas. 
Goleman, D. 1995. Emotional Intellegence, Alih Bahasa, T. Hermaya, Jakarta : Gramedia Pustaka Utama.

Harmoko, R., Agung, 2005. Kecerdasan Emosional. Binuscareer.com

Kartini,Kartono.2005.Pemimpin dan Kepemimpinan.Jakarta: Rajawali Pers.

Kinicki \& Kreitner.2008.Organizational Behavior:Key Concept, Skill and Best Practice.New York: Mc Graw Hill Irwin.

Luthans,Fred.2008.Organizational Behavior.New York USA Mc Graw Hill $11^{\text {th }}$ Edition.

Nursyamsi,N.2014.Pengembangan

Kepribadian Guru.Jurnal Tarbiyah IAIN Imam Bonjol:Padang.ISSN 141075 46, ISSN 2355-7893.

Ratnasari, Dian dan Ani Muttaqiyathun, Ani. 2012. Pengaruh Kecerdasan emosional terhadap kinerja guru pada SD yang terletak di Wilayah Tegaltirto. Literatur Reviu. http://manajemen.uad.ac.id [10/10/2012].
Riadi, Edi.tanpa tahun. Pengaruh kepribadian, kecerdasan emosional, dan perilaku kewarganegaraan organisasi terhadap kinerja kepala sekolah menengah atas dan kejuruan di kota Tangerang.Jurnal Manajemen Pendidikan: Universitas Muhammadiyah Tangerang.

Robbins, S.2003.Perilaku Organisasi.Index,Jakarta.

Schutte, N.S., Malouff. J.M., Bobik, C., Coston. T.R., Greeson. C., Jedlicka, C., Rhodes. E., and Wnedorf, G. 2001. Emotional Intelligence and Interpersonal Relations. The Journal Social Psychology. 141, 4, 523-536.

Sri Hastuti, 2012. Peran EQ Dalam Pembentukan Pribadi Bidan. http://esrihastuti.blogspot.com. [10/10/201].

Tilaar, H.A.R. 1997. Pengembangan Sumber Daya Manusia Dalam Era Globalisasi. Grasindo: Jakarta.

Widodo, A.T.2002. Kecerdasan Emosional untuk Mencapai Puncak Prestasi. Jakarta: Gramedia 